\title{
Comparison of Colonoscopy Results of Turkish and Syrian Patients, Frequency of Incomplete Colonoscopy and Causes of Incomplete Colonoscopy
}

\author{
Türk ve Suriyeli Hastaların Kolonoskopi Sonuçları, İnkomplet Kolonoskopi \\ Sıklığı ve İnkomplet Kolonoskopi Nedenlerinin Karşılaştırılması
}

\author{
(1) Durmuş Ali Çetin1, (1) Mehmet Patmano2 \\ 1 University of Health Sciences Tepecik Training and Research Hospital, Clinic of General Surgery, İzmir, Turkey \\ 2Şanlıurfa Training and Research Hospital, Clinic of General Surgery, Şanlıurfa, Turkey
}

\section{HIIIIII| ABSTRACT}

Aim: Colonoscopy is a frequently used procedure for the diagnosis of the colorectal diseases. In this study, we aimed to present demographic, endoscopic, and histopathological characteristics, the frequency of incomplete colonoscopy, and causes of incomplete colonoscopy of Turkish and Syrian patients who had undergone colonoscopy in our hospital.

Method: The demographic, clinical, and histopathological characteristics of Turkish and Syrian patients who had undergone colonoscopy in our hospital between August 2017 and March 2020 were compared.

Results: A total of 2,285 patients were included in the study, of which 1,175 (51.4\%) were female, 1,110 (48.6\%) were male, and the mean age was $46.30 \pm 15.33$ years. The rate of incomplete colonoscopy was $18.3 \%$. It was observed that the male gender, incomplete colonoscopy rate, insufficient bowel cleansing rate, and patients with Boston bowel cleansing score of zero and one were higher in the Syrian patient group (p<0.001). The polyp detection rate was $14.6 \%$ in the Turkish patient group and $8.8 \%$ in the Syrian patient group ( $\mathrm{p}=0.035)$. Advanced age $(\mathrm{p}=0.002)$, ethnicity $(\mathrm{p}<0.001)$, and insufficient bowel cleansing $(\mathrm{p}<0.001)$ were significant factors for incomplete colonoscopy.

Conclusion: In our study, the higher rate of incomplete colonoscopy and insufficient bowel cleansing and the low rate of polyp detection in the Syrian patient group remained below the current literature recommendations. We think that insufficient information about bowel cleansing preparation is responsible for this finding due to the current socio-economic conditions and communication problem (language disability) in our region.

Keywords: Colonoscopy, incomplete colonoscopy, Syrian patients

\section{|IIIIIII|| ÖZ}

Amaç: Kolonoskopi kolorektal hastalıkların tanısında sıklıkla kullanılan bir işlemdir. Bu çalışmamızda endoskopi ünitemizde kolonoskopi yapılan Türk ve Suriyeli hastaların demografik, endoskopik ve histopatolojik özelliklerini, inkomplet kolonoskopi sıklığını ve inkomplet kolonoskopi nedenlerini sunmayı amaçladık.

Yöntem: Ağustos 2017-Mart 2020 tarihleri arasında hastanemizde kolonoskopi yapılan Türk ve Suriyeli hastaların demografik, klinik ve histopatolojik özellikleri karşılaştırıldı. İnkomplet kolonoskopi nedenleri ve inkomplet kolonoskopiye etki eden faktörler incelendi.

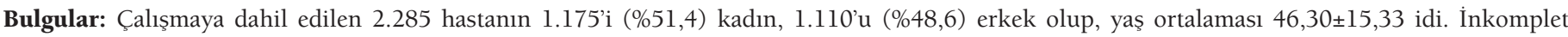
kolonoskopi oranı \%18,3 idi. Erkek cinsiyetin, inkomplet kolonoskopi oranının, yetersiz barsak temizliği oranının ve Boston barsak temizliği skoru 0 ve 1 olan hastaların Suriyeli hasta grubunda daha yüksek olduğu görüldü ( $<<0,001)$. Polip saptanma oranı Türk hasta grubunda \%14,6, Suriyeli hasta grubunda ise \%8,8 idi $(\mathrm{p}=0,035)$. İleri yaş $(\mathrm{p}=0,002)$, etnik köken $(\mathrm{p}<0,001)$ ve yetersiz barsak temizliği ( $<<0,001)$ inkomplet kolonoskopi lehine anlamlı bulundu.

Sonuç: Çalışmamızda Suriyeli hasta grubunda yüksek inkomplet kolonoskopi ve yetersiz barsak temizliği oranı ile düşük polip saptama oranı güncel literatür önerilerinin altında kalmıştır. Bu durumun bölgemizdeki mevcut sosyoekonomik şartlar ve iletişim probleminden (dil engeli) dolayı işlem öncesi barsak temizliği hazırlık bilgilendirmelerine uyumsuzluktan kaynaklandığını düşünmekteyiz.

Anahtar Kelimeler: Kolonoskopi, inkomplet kolonoskopi, Suriyeli hastalar

回 Address for Correspondence/Yazışma Adresi: Durmuş Ali Çetin, MD,

University of Health Sciences Tepecik Training and Research Hospital, Clinic of General Surgery, İzmir, Turkey

E-mail: drdurmusalicetin@gmail.com ORCID ID: orcid.org/0000-0003-3012-6774

Received/Gelis Tarihi: 21.01.2021 Accepted/Kabul Tarihi: 14.02.2021

${ }^{\odot}$ Copyright 2021 by Turkish Society of Colon and Rectal Surgery

Turkish Journal of Colorectal Disease published by Galenos Publishing House. 


\section{Introduction}

Colonoscopy (CS) is a reliable method with high diagnostic accuracy and good patient tolerance under sedation. It is frequently used in daily practice for the diagnosis and treatment of colorectal diseases. It is the gold-standard method for detecting colorectal pathologies. ${ }^{1}$ CS is a procedure performed for both diagnostic and therapeutic indications. In addition to its diagnostic properties, since it may be used therapeutically, it is also used frequently for the treatment purposes in cases such as colon polyps, lower gastrointestinal bleeding, stenosis lesions, and volvulus. ${ }^{2,3}$ CS is recommended for the assessment of lower gastrointestinal system diseases such as colorectal cancer screenings, colorectal polyps, colorectal cancer, and inflammatory bowel disease. ${ }^{4,5,6}$ The purpose of a CS is to examine the entire colon to the caecum. A successful CS provides precise imaging of the mucosal surface of the colon. However, this is not always possible. Incomplete CS rates are reported at a rate of $4 \%-25 \% .{ }^{2,7,8,9,10}$ The success of the CS procedure is affected by many factors such as age, gender, comorbid disease, history of abdominal surgery, and sufficient bowel cleansing. Sufficient bowel preparation is the most critical factor affecting complete CS rates. Insufficient bowel cleansing rate in all CS procedures is around 20\%$25 \% .^{7,10}$ In this study, we aimed to present the demographic, endoscopic, and histopathological characteristics, the frequency of incomplete colonoscopy, and the causes of incomplete colonoscopy of Turkish and Syrian patients who had undergone colonoscopy in our endoscopy unit.

\section{Materials and Methods}

\section{Study Design and Data}

The records of patients who had undergone colonoscopy at Şanlıurfa Training and Research Hospital endoscopy unit between August 2017 and March 2020 were reviewed retrospectively. The study was designed according to the Helsinki Declaration. The study was approved by the Harran University Clinical Studies Ethics Committee (approval no: HRU/20.11.37). Written informed consent was obtained from all patients before the procedure. Patients who had undergone diagnostic and therapeutic procedures due to gastrointestinal bleeding, volvulus, sub-ileus, and ileus under emergency conditions, patients who had rectosigmoidoscopy procedures for emergency and elective necessities, cases with polyposis syndrome, cases with more than three polyps, and cases for whom the pathology result were not reached were excluded from the study. Age, gender, nationality, procedure indications, complete/incomplete CS number, optimal/suboptimal CS number, incomplete CS reasons, Boston bowel preparation scale score, presence of polyp, previous colorectal surgery, benign and malignant colorectal diseases detected, benign perianal diseases detected, and complications related to the procedure were recorded. Turkish patients who had undergone CS constituted Group 1, and Syrian patients constituted Group 2. The demographic and clinical characteristics of the two groups were compared. Demographic data and bowel preparation scores of incomplete and complete CS cases were compared.

\section{Mechanical Bowel Preparation}

Patients who were scheduled for the CS procedure were recommended a pulpless liquid food regimen three days before the procedure and were given an informative form describing the diet and mechanical bowel cleansing before the procedure. One day before the procedure, $2 \mathrm{X}-\mathrm{M}$ diet solutions ${ }^{\circledR} 150 \mathrm{~mL} \quad(300 \mathrm{mg}$ ) (Senoside-A+B-calcium solution) or Phospho soda ${ }^{\circledR}$ and/or Fleet phospho soda ${ }^{\circledR}$ $90 \mathrm{~mL}$ (Dibasic-sodium-phosphate+monophasic-sodiumphosphate) laxative solution were given orally. Intestinal cleansing was performed one day before the procedure and on the morning of the procedure, by giving a total of two BT enema ${ }^{\circledR} 210 \mathrm{~mL}$ (Dibasic-sodium-phosphate+monophasicsodium-phosphate) rectally. Polyethylene glycol solution (Pegdin ${ }^{\circledR}$ and/or Golytely ${ }^{\circledR}$ ) was given to patients whose sodium phosphate usage was inappropriate (e.g., kidney disease.). Colon cleansing was evaluated in four categories according to the Boston bowel preparation scale score ${ }^{11,12}$ as follows: "Score 0, Unprepared colon segment with mucosa was not visible because of solid stool that cannot be cleared; Score 1, Portion of the mucosa of the colon segment seen, but other areas of the colon segment are not seen well because of staining, residual stool, and/or opaque liquid; Score 2, Minor amount of residual staining, small fragments of stool, and/or opaque liquid, but mucosa of colon segment is seen well; and Score 3, Entire mucosa of colon segment seen well, with no residual staining, small fragments of stool, or opaque liquid".

\section{Colonoscopy and Anesthesia Procedure}

All procedures were performed by a gastroenterologist, gastroenterology surgeon, or general surgery specialist having performed at least 500 CS experiences. Patients were positioned in the left lateral decubitus position. Before the procedure, sedation was performed using a combination of midazolam, propofol, and fentanyl under the observation of an anesthesiologist. All endoscopic procedures were performed with Fujinon ${ }^{\circledR}$ (Fujinon, Willich, Germany) video colonoscopy devices. Complete colonoscopy was defined as visualization of the ileocecal valve and appendix mouth or the terminal ileum. Forceps polypectomy was applied to polyps detected during the procedure that were 
$<5 \mathrm{~mm}$ in size, and snare polypectomy was applied to polyps $>10 \mathrm{~mm}$. Forceps polypectomy or snare polypectomy was applied to polyps 5-10 $\mathrm{mm}$ in size. Polypectomy procedures were performed either en-block or piecemeal.

\section{Statistical Analysis}

The Statistical Package for the Social Sciences (SPSS 25 Inc., Chicago, IL, USA) software was used for biostatistical analyses. The data obtained from the patients participating in the study were expressed as the mean, standard deviation values, and as a percentage where necessary. The Kolmogorov-Smirnov test checked the distribution of the data. Data with normal distribution were analyzed by the student t-test. Group analysis of non-parametric data was made with Mann-Whitney U test. Categorical groups were compared with the chi-square test. A p-value of $<0.05$ was considered statistically significant.

\section{Results}

A total of 2,285 patients who met the study criteria were included in the study. 1,175 (51.4\%) of the patients were female, and 1,110 (48.6\%) were male, and the mean age was $46.30 \pm 15.33$ years. There were 2,114 (92.5\%) patients in Group 1 and 171 (7.5\%) patients in Group 2. CS was completed in 1867 (81.7\%) patients and performed most frequently due to rectal bleeding and/or anal burning-pain (23.2\%). The CS procedure was not completed in 418 (18.3\%) of the patients. The most seen cause of incomplete CS was insufficient bowel cleansing at a rate of $85.2 \%$. The rate of incomplete CS in Turkish patients was $17.2 \%$, and the rate of incomplete colonoscopy in Syrian patients was $31.6 \%$. Insufficient bowel cleansing rate was found as $14.5 \%$ in Turkish patients and $28.7 \%$ in Syrian patients. Looping with a rate of $7.7 \%(32 / 418)$ was the most common cause of the incomplete CS in patients who had adequate bowel cleansing. It was observed that the male gender, incomplete CS rate, insufficient bowel cleansing rate, and the patients with Boston bowel cleansing score of zero and one were higher in the Syrian group $(\mathrm{p}<0.001)$. The ileum intubation rate was higher in the Turkish group and was found to be statistically significant $(\mathrm{p}=0.022)$. Complications were seen in four $(0.17 \%)$ patients after colonoscopy. Bleeding was observed in two $(0.08 \%)$ patients after colonoscopic polypectomy, and perforation was observed in two $(0.08 \%)$ patients. Hemostasis was achieved with sclerotherapy and endoscopic clips in patients who developed bleeding due to the procedure. In one case that developed colon perforation, laparotomy was performed upon the development of peritoneal irritation findings, and the perforated area was sutured with primary closure. The other case that had perforation was followed up conservatively due to the absence of peritoneal irritation findings. All patients who developed complications were discharged without any problems. When the clinical and histopathological characteristics of the colonoscopy findings of both groups were compared, the normal colonoscopy number was 732 (34.6\%) in the Turkish patient group and 51 (29.8\%) in the Syrian patient group. This difference was statistically significant $(\mathrm{p}<0.001)$. The polyp detection rate was $14.6 \%$ in the Turkish patient group and $8.8 \%$ in the Syrian patient group, and this result was statistically significant $(\mathrm{p}=0.035)$. The most common colonoscopically detected pathology was hemorrhoids in $616(27 \%)$ patients. No statistically significant difference was found in either group in terms of colorectal tumor or colitis detection rates. When the histopathological characteristics of cases with colorectal tumor and colitis were compared, it was found that the rate of adenocarcinoma was higher in the Syrian patient group, and the rates of other colitis subtypes other than diversion colitis were higher in the Turkish patient group; these findings were statistically significant $(\mathrm{p}=0.002$ and $\mathrm{p}<0.001)$. A total of 440 polyps were detected in 324 (14.2\%) out of 2285 patients. The mean age of the patients in which a polyp was found was $52.62 \pm 12.92$ years. Among them, 179 (55.2\%) were male, and 145 (44.8\%) were female. While a single polyp was found in 237 patients ( $73.1 \%$ ) during colonoscopy, 58 patients (17.9\%) had two polyps, and 29 patients had three polyps (9\%). Colon polyps were most frequently detected in the sigmoid colon (27.5\%), followed by the rectum (25.9\%), and descending colon (12.3\%). When the histopathological characteristics of colon polyps were examined, it was seen that the vast majority were tubular adenoma $(50.9 \%)$ and hyperplastic polyps (33.4\%). Data comparing demographic, clinical, endoscopic characteristics, and histopathological characteristics of the patients are presented in Tables 1 , 2 , and 3 . When the data obtained from the comparison of the complete and incomplete CS groups were examined, among incomplete CS patients, 206 (49.3\%) were male, and $212(50.7 \%)$ were female. The mean age of the complete CS patients was $45.81 \pm 14.95$ years, and the mean age of incomplete CS patients was $48.48 \pm 16.79$ years. Age ( $\mathrm{p}=0.002)$, ethnicity $(\mathrm{p}<0.001)$, and insufficient bowel cleansing $(p<0.001)$ were statistically significant in favor of incomplete CS (Table 4).

\section{Discussion}

$\mathrm{CS}$ is a frequently used method in daily practice in the diagnosis of colorectal diseases. Since it may be used therapeutically, it is accepted as the gold-standard method in the examination of the colon and terminal ileum. ${ }^{1}$ Most patients undergo lower gastrointestinal endoscopy due to rectal bleeding and constipation. These complaints may be due to benign anorectal diseases or may be seen in colorectal cancers. 
Table 1. Demographic, clinical, endoscopic features, incomplete colonoscopy rate and causes of incomplete colonoscopy in patients undergoing colonoscopy

\begin{tabular}{|c|c|c|c|c|c|}
\hline \multicolumn{2}{|l|}{ Variables } & $\begin{array}{l}\text { Group } 1 \\
\text { (Turkish patients) } \\
(\mathrm{n}, \%) \\
(\mathrm{n}=2114)\end{array}$ & $\begin{array}{l}\text { Group } 2 \\
\text { (Syrian patients) } \\
(\mathrm{n}, \%) \\
(\mathrm{n}=171)\end{array}$ & $\begin{array}{l}\text { Numeric and } \\
\text { percentage value } \\
(n=2285) \\
(100 \%)\end{array}$ & $\mathrm{p}$ value \\
\hline \multicolumn{2}{|c|}{ Age $($ mean \pm SD $)($ median $)$} & $\begin{array}{l}46.28 \pm 15.24 \\
46(17-95)\end{array}$ & $\begin{array}{l}46.55 \pm 16.49 \\
45(19-88)\end{array}$ & $\begin{array}{l}46.30 \pm 15.33 \\
46(17-95)\end{array}$ & 0.969 \\
\hline \multirow{2}{*}{ Sex } & Female & $1116(52.8 \%)$ & $59(34.5 \%)$ & $1175(51.4 \%)$ & \multirow{2}{*}{$<0.001 *$} \\
\hline & Male & $998(47.2 \%)$ & $112(65.5 \%)$ & $1110(48.6 \%)$ & \\
\hline \multirow{13}{*}{$\begin{array}{l}\text { Indications for } \\
\text { colonoscopy }\end{array}$} & Rectal bleeding and/or anal burning-pain & $485(22.9 \%)$ & $46(26.9 \%)$ & $531(23.2 \%)$ & \multirow{13}{*}{0.187} \\
\hline & Constipation & $447(21.1 \%)$ & $42(24.6 \%)$ & $489(21.4 \%)$ & \\
\hline & Abdominal pain & $357(16.9 \%)$ & $32(18.7 \%)$ & $389(17 \%)$ & \\
\hline & Anemia & $180(8.5 \%)$ & $13(7.6 \%)$ & $193(8.4 \%)$ & \\
\hline & Diarrhea & $128(6.1 \%)$ & $5(2.9 \%)$ & $133(5.8 \%)$ & \\
\hline & Screening & $110(5.2 \%)$ & $6(3.5 \%)$ & $116(5.1 \%)$ & \\
\hline & Fecal occult blood positive & $89(4.2 \%)$ & $6(3.5 \%)$ & $95(4.2 \%)$ & \\
\hline & Change in defecation habits & $67(3.2 \%)$ & $5(2.9 \%)$ & $72(3.2 \%)$ & \\
\hline & Follow-up after polipectomy & $69(3.3 \%)$ & $1(0.6 \%)$ & $70(3.1 \%)$ & \\
\hline & Family history of CRC & $63(3 \%)$ & $2(1.2 \%)$ & $65(2.8 \%)$ & \\
\hline & Operated colon/rectum tumor follow-up & $38(1.8 \%)$ & $3(1.8 \%)$ & $41(1.8 \%)$ & \\
\hline & Increased colon or ileum wall thickness in CT & $30(1.4 \%)$ & $6(3.5 \%)$ & $36(1.6 \%)$ & \\
\hline & Other reasons & $51(2.4 \%)$ & $4(2.3 \%)$ & $55(2.4 \%)$ & \\
\hline \multirow{2}{*}{$\begin{array}{l}\text { Colonoscopy } \\
\text { completion } \\
\text { status }\end{array}$} & Complete colonoscopy & $1750(82.8 \%)$ & $117(68.4 \%)$ & $1867(81.7 \%)$ & \multirow{2}{*}{$<0.001 *$} \\
\hline & Incomplete colonoscopy & $364(17.2 \%)$ & $54(31.6 \%)$ & $418(18.3 \%)$ & \\
\hline \multirow{5}{*}{$\begin{array}{l}\text { Causes of } \\
\text { incomplete } \\
\text { colonoscopy }\end{array}$} & İnadequate bowel preparation & $307(14.5 \%)$ & $49(28.7 \%)$ & $356(15.6 \%)$ & \multirow{5}{*}{$<0.001^{*}$} \\
\hline & Looping and/or redundancy & $31(1.5 \%)$ & $1(0.6 \%)$ & $32(1.4 \%)$ & \\
\hline & Tumor obstruction & $12(0.6 \%)$ & $3(1.8 \%)$ & $15(0.7 \%)$ & \\
\hline & Discomfort and intolerance & $11(0.5 \%)$ & $1(0.6 \%)$ & $12(0.5 \%)$ & \\
\hline & Angulation & $3(0.1 \%)$ & $0(0 \%)$ & $3(0.1 \%)$ & \\
\hline \multirow{2}{*}{$\begin{array}{l}\text { Ileum intubation } \\
\text { status }\end{array}$} & Yes & $513(24.3 \%)$ & $27(15.8 \%)$ & $540(23.6 \%)$ & \multirow{2}{*}{$0.012 *$} \\
\hline & No & $1601(75.7 \%)$ & 144 (84.2\%) & $1745(76.4 \%)$ & \\
\hline \multirow{4}{*}{$\begin{array}{l}\text { Bowel } \\
\text { preparation } \\
\text { score }\end{array}$} & 0 & 307 (14.5\%) & 49 (28.7\%) & $356(15.6 \%)$ & \multirow{4}{*}{$<0.001^{*}$} \\
\hline & 1 & $151(7.1 \%)$ & $20(11.7 \%)$ & $171(7.5 \%)$ & \\
\hline & 2 & 401 (19\%) & 34 (19.9\%) & 435 (19\%) & \\
\hline & 3 & $1255(59.4 \%)$ & 68 (39.8\%) & $1323(57.9 \%)$ & \\
\hline \multirow{2}{*}{ Complication } & Bleeding & $2(0.09 \%)$ & $0(0 \%)$ & $2(0.08 \%)$ & \multirow{2}{*}{0.850} \\
\hline & Perforation & $2(0.09 \%)$ & $0(0 \%)$ & $2(0.08 \%)$ & \\
\hline
\end{tabular}

SD: Standard deviation, CRC: Colorectal cancer, CT: Computed tomography 
Table 2. Clinical and histopathological features, colon localizations of findings detected in colonoscopies

\begin{tabular}{|c|c|c|c|c|c|}
\hline \multicolumn{2}{|l|}{ Variables } & $\begin{array}{l}\text { Group-1 } \\
\text { (Turkish patients) } \\
(n, \%)(n=2.114)\end{array}$ & $\begin{array}{l}\text { Group-2 } \\
\text { (Syrian patients) } \\
(n, \%)(n=171)\end{array}$ & $\begin{array}{l}\text { Numeric and percentage } \\
\text { value }(n=2.285)(100 \%)\end{array}$ & $\mathrm{p}$ value \\
\hline \multicolumn{2}{|l|}{ Normal findings } & $732(34.6 \%)$ & $51(29.8 \%)$ & $783(34.3 \%)$ & $<0.001 *$ \\
\hline \multicolumn{2}{|l|}{ Polyp } & $309(14.6 \%)$ & $15(8.8 \%)$ & $324(14.2 \%)$ & $0.035 *$ \\
\hline \multicolumn{2}{|l|}{ Hemorrhoids } & $572(27.1 \%)$ & $44(25.7 \%)$ & $616(27 \%)$ & 0.707 \\
\hline \multicolumn{2}{|l|}{ Anal fissure } & $146(6.9 \%)$ & $6(3.5 \%)$ & $152(6.7 \%)$ & 0.086 \\
\hline \multicolumn{2}{|l|}{ Perianal fistula } & $15(0.7 \%)$ & $1(0.6 \%)$ & $16(0.7 \%)$ & 0.851 \\
\hline \multicolumn{2}{|l|}{ Diverticulum } & $66(3.1 \%)$ & $1(0.6 \%)$ & $67(2.9 \%)$ & 0.059 \\
\hline \multicolumn{2}{|c|}{ Previous operation and anastomosis status } & $35(1.7 \%)$ & $5(2.9 \%)$ & $40(1.8 \%)$ & 0.224 \\
\hline \multicolumn{2}{|l|}{ Solitary rectal ulcer } & $8(0.4 \%)$ & $1(0.6 \%)$ & $9(0.4 \%)$ & 0.679 \\
\hline \multicolumn{2}{|l|}{ Lipoma } & $25(1.2 \%)$ & $3(1.8 \%)$ & $28(1.2 \%)$ & 0.513 \\
\hline \multicolumn{2}{|l|}{ Colorectal tumor } & $32(1.5 \%)$ & $6(3.5 \%)$ & $38(1.7 \%)$ & 0.050 \\
\hline \multirow{8}{*}{$\begin{array}{l}\text { Colorectal tumor } \\
\text { localizations }\end{array}$} & Caecum & $3(0.1 \%)$ & $2(1.2 \%)$ & \multirow{8}{*}{$38(1.7 \%)$} & \multirow{8}{*}{0.068} \\
\hline & Ascending colon & $2(0.09 \%)$ & $0(0 \%)$ & & \\
\hline & Hepatic flexure & $3(0.1 \%)$ & $0(0 \%)$ & & \\
\hline & Transverse colon & $1(0.04 \%)$ & $0(0 \%)$ & & \\
\hline & Descending colon & $1(0.04 \%)$ & $0(0 \%)$ & & \\
\hline & Sigmoid & $5(0.2 \%)$ & $0(0 \%)$ & & \\
\hline & Rectosigmoid & $3(0.14 \%)$ & $0(0 \%)$ & & \\
\hline & Rectum & $14(0.7 \%)$ & $4(2.3 \%)$ & & \\
\hline \multirow{3}{*}{$\begin{array}{l}\text { Histopathological features } \\
\text { of colorectal tumor cases }\end{array}$} & Adenocarcinoma & $31(1.5 \%)$ & $5(2.9 \%)$ & \multirow{3}{*}{$38(1.7 \%)$} & \multirow{3}{*}{$0.002 *$} \\
\hline & Malign epithelial tumor & $1(0.04 \%)$ & $0(0 \%)$ & & \\
\hline & Neuroendocrine tumor & $0(0 \%)$ & $1(0.6 \%)$ & & \\
\hline Colitis and/or ileit & & $141(6.7 \%)$ & $12(7 \%)$ & $153(6.7 \%)$ & 0.861 \\
\hline \multirow{5}{*}{$\begin{array}{l}\text { Localization of cases with } \\
\text { colitis and/or ileitis }\end{array}$} & Terminal ileit & $42(2 \%)$ & $1(0.6 \%)$ & \multirow{5}{*}{$153(6.7 \%)$} & \multirow{5}{*}{0.587} \\
\hline & $\begin{array}{l}\text { Right colon } \\
\text { involvement }\end{array}$ & $3(0.1 \%)$ & $0(0 \%)$ & & \\
\hline & Left colon involvement & $54(2.6 \%)$ & $5(2.9 \%)$ & & \\
\hline & Proctitis & $22(\%)$ & $3(1.8 \%)$ & & \\
\hline & Pancolitis & $20(0.9 \%)$ & $3(1.8 \%)$ & & \\
\hline \multirow{13}{*}{$\begin{array}{l}\text { Histopathological features } \\
\text { of colitis and/or ileitis }\end{array}$} & Ulcerative colitis & $55(2.6 \%)$ & $2(1.2 \%)$ & \multirow{13}{*}{$153(6.7 \%)$} & \multirow{13}{*}{$<0.001 *$} \\
\hline & Crohn's disease & $24(1.1 \%)$ & $1(0.6 \%)$ & & \\
\hline & Nonspecific colitis & $25(1.2 \%)$ & $1(0.6 \%)$ & & \\
\hline & Infectious colitis & $8(0.4 \%)$ & $2(1.2 \%)$ & & \\
\hline & Eosinophilic colitis & $2(0.09 \%)$ & $0(0 \%)$ & & \\
\hline & Collagenous colitis & $1(0.04 \%)$ & $0(0 \%)$ & & \\
\hline & Diversion colitis & $0(0 \%)$ & $5(2.9 \%)$ & & \\
\hline & Radiation colitis & $1(0.04 \%)$ & $0(0 \%)$ & & \\
\hline & Actinomyces infection & $1(0.04 \%)$ & $0(0 \%)$ & & \\
\hline & Non-specific ileitis & $13(0.6 \%)$ & $1(0.6 \%)$ & & \\
\hline & $\begin{array}{l}\text { Nodular lymphoid } \\
\text { hyperplasia }\end{array}$ & $7(0.3 \%)$ & $0(0 \%)$ & & \\
\hline & Eosinophilic ileitis & $1(0.04 \%)$ & $0(0 \%)$ & & \\
\hline & Normal ileum mucosa & $3(0.1 \%)$ & $0(0 \%)$ & & \\
\hline \multicolumn{2}{|l|}{ Anjiodysplasia } & $2(0.09 \%)$ & $1(0.6 \%)$ & $3(0.1 \%)$ & 0.089 \\
\hline Rectovaginal fistula & & $2(0.09 \%)$ & $0(0 \%)$ & $2(0.1 \%)$ & 0.687 \\
\hline Foreign body in the rectum & & $1(0.04 \%)$ & $0(0 \%)$ & $1(0.04 \%)$ & 0.776 \\
\hline
\end{tabular}


Table 3. Demographic, clinical and histopathological features of patients with polyp and polypectomy

\begin{tabular}{|c|c|c|c|}
\hline \multicolumn{2}{|l|}{ Variables } & \multirow{2}{*}{$\begin{array}{l}\text { Numeric (n) } \\
52.62 \pm 12.92\end{array}$} & \multirow[t]{2}{*}{ Percentage value (\%) } \\
\hline Age $($ mean \pm SD $)$ & & & \\
\hline \multirow{2}{*}{ Sex } & Female & $145 / 324$ & $44.8 \%$ \\
\hline & Male & $179 / 324$ & $55.2 \%$ \\
\hline \multirow{2}{*}{ Nationality } & Turkish patients & $309 / 324$ & $95.4 \%$ \\
\hline & Syrian patients & $15 / 324$ & $4.6 \%$ \\
\hline \multirow{3}{*}{ Number of polyp } & 1 & $237 / 440$ & $73.1 \%$ \\
\hline & 2 & $58 / 440$ & $17.9 \%$ \\
\hline & 3 & $29 / 440$ & $9 \%$ \\
\hline \multicolumn{2}{|c|}{ Polyp diameter (median, min-max) } & \multicolumn{2}{|l|}{6 mm (min:3 mm-max:40 mm) } \\
\hline \multirow{4}{*}{ Polyp diameter } & $\leq 5 \mathrm{~mm}$ & $198 / 440$ & $45 \%$ \\
\hline & $5-10 \mathrm{~mm}$ & $170 / 440$ & $38.6 \%$ \\
\hline & $10-20 \mathrm{~mm}$ & $62 / 440$ & $14.1 \%$ \\
\hline & $\geq 20 \mathrm{~mm}$ & $10 / 440$ & $2.3 \%$ \\
\hline \multirow{9}{*}{ Polyp localization } & Caecum & $29 / 440$ & $6.6 \%$ \\
\hline & Ascending colon & $38 / 440$ & $8.6 \%$ \\
\hline & Hepatic flexure & $19 / 440$ & $4.3 \%$ \\
\hline & Transverse colon & $52 / 440$ & $11.8 \%$ \\
\hline & Splenic flexure & $5 / 440$ & $1.1 \%$ \\
\hline & Descending colon & $54 / 440$ & $12.3 \%$ \\
\hline & Sigmoid & $121 / 440$ & $27.5 \%$ \\
\hline & Rectosigmoid & $8 / 440$ & $1.8 \%$ \\
\hline & Rectum & $114 / 440$ & $25.9 \%$ \\
\hline \multirow{3}{*}{ Polyp type } & Diminutive & $198 / 440$ & $45 \%$ \\
\hline & Sesil & $161 / 440$ & $36.6 \%$ \\
\hline & Pedicellate & $81 / 440$ & $18.4 \%$ \\
\hline \multirow{2}{*}{ Type of polypectomy } & Forceps & $343 / 440$ & $78 \%$ \\
\hline & Snare & $97 / 440$ & $22 \%$ \\
\hline \multirow{10}{*}{ Histopathological diagnosis } & Tubular adenoma & $224 / 440$ & $50.9 \%$ \\
\hline & Tubuloillous adenoma & $24 / 440$ & $5.5 \%$ \\
\hline & Villous adenoma & $2 / 440$ & $0.5 \%$ \\
\hline & Intramucosal carcinoma & $2 / 440$ & $0.5 \%$ \\
\hline & Hyperplastic polyp & $147 / 440$ & $33.4 \%$ \\
\hline & Inflammatory polyp & $22 / 440$ & $5 \%$ \\
\hline & Hamartomatous polyp & $3 / 440$ & $0.7 \%$ \\
\hline & Juvenile polyp & $3 / 440$ & $0.7 \%$ \\
\hline & Mucosal tissue & $12 / 440$ & $2.7 \%$ \\
\hline & Serrated adenoma & $1 / 440$ & $0.2 \%$ \\
\hline \multirow{3}{*}{ Presence of dysplasia } & None & $380 / 440$ & $86.4 \%$ \\
\hline & Low grade dysplasia & $49 / 440$ & $11.1 \%$ \\
\hline & High grade dysplasia & $11 / 440$ & $2.5 \%$ \\
\hline
\end{tabular}


Table 4. Comparison of complete and incomplete colonoscopy patients

\begin{tabular}{|c|c|c|c|c|}
\hline \multicolumn{2}{|l|}{ Variables } & $\begin{array}{l}\text { Complete colonoscopy (n, \%) } \\
\text { total: } 1,867(81.7 \%)\end{array}$ & $\begin{array}{l}\text { Incomplete colonoscopy (n, \%) } \\
\text { total: } 418(18.3 \%)\end{array}$ & $\mathrm{p}$ value \\
\hline \multirow{2}{*}{\multicolumn{2}{|c|}{ Age $($ mean \pm SD $)($ median $)$}} & $45.81 \pm 14.95$ & $48.48 \pm 16.79$ & \multirow{2}{*}{$0.002 *$} \\
\hline & & $45(17-95)$ & $48.5(17-93)$ & \\
\hline \multirow{2}{*}{ Sex } & Female & $963(51.6 \%)$ & $212(50.7 \%)$ & \multirow{2}{*}{0.750} \\
\hline & Male & $904(48.4 \%)$ & $206(49.3 \%)$ & \\
\hline \multirow{2}{*}{ Nationality } & Turkish patients & $1750(82.8 \%)$ & $364(17.2 \%)$ & \multirow{2}{*}{$<0.001^{*}$} \\
\hline & Syrian patients & 117 (68.4\%) & $54(31.6 \%)$ & \\
\hline \multirow{4}{*}{ Bowel preparation score } & 3 & 1281 (68.6\%) & $42(10 \%)$ & \multirow{4}{*}{$<0.001 *$} \\
\hline & 2 & $419(22.4 \%)$ & $16(3.8 \%)$ & \\
\hline & 1 & $167(8.9 \%)$ & $4(1 \%)$ & \\
\hline & 0 & $0(0 \%)$ & $356(85.2 \%)$ & \\
\hline
\end{tabular}

SD: Standard deviation

Individuals $<50$ years of age are recommended to have a test for fecal occult blood and recto-sigmoidoscopy every 3-5 years by the American Cancer Society. ${ }^{13}$ It was found that the most frequent cause of CS performed in our endoscopy unit was rectal bleeding and/or anal burning-pain at a rate of $23.2 \%$.

CS targets to examine the entire colon to the caecum. The success of the CS is defined as the intubation of the caecum. It is suggested that the caecum intubation rate should be around 90\%-95\%. Socio-economic factors and language barriers in some patient populations may require further educational effort before the procedure to reach the recommended caecum intubation rate. ${ }^{2}$ Certainly, sufficient bowel cleansing is essential for a standard evaluation. Sufficient bowel cleansing reduces caecum intubation time and allows the entire colonic mucosa to be examined, increasing the rate of polyp detection. ${ }^{10,14}$ Incomplete CS rates are reported to be $4 \%-25 \%$, and insufficient bowel cleansing rate as $20 \%-25 \%{ }^{7,8,9,10,15}$ In the study of Hendry et al. ${ }^{16}$ which included 10,571 patients, insufficient bowel preparation was reported at a rate of $16.9 \%$. In the study by Bowles et al. ${ }^{17}$, the rate of reaching the caecum was $76.9 \%$, and the insufficient bowel cleansing rate was $19.6 \%$. Koido et al. ${ }^{7}$ reported an insufficient bowel cleansing rate of $5 \%$ in their study involving 11,812 patients. It is suggested that the sufficient bowel cleansing rate should be $\geq 85 \% .{ }^{10}$ Our success in reaching the caecum was $81.7 \%(1,867 / 2,285)$, which is below the recommended level. Incomplete colonoscopy incidence was $18.3 \%$, and insufficient bowel cleansing was found to be the most important reason among $356(15.6 \%)$ cases. The rate of incomplete colonoscopy in Turkish patients was $17.2 \%$ and $31.6 \%$ in Syrian patients. The insufficient bowel cleansing rate was $14.5 \%$ in Turkish patients and 28.7\% in Syrian patients. Both the incomplete
CS rate and inadequate bowel cleansing rate were higher in the Syrian patient group. Colonoscopy could not be completed in $18.3 \%$ of the patients in this study, in which we examined the frequency and reasons of incomplete colonoscopy. A significant relationship was determined between advanced age, ethnicity (Syrian), and insufficient bowel cleansing (Boston score 0) with incomplete CS. We think that our results are due to the existing socio-economic factors and language disability in our region. Incompatibility of the patients with information regarding bowel cleansing before the procedure causes unsatisfactory results.

One of the most common pathologies detected in the patients who underwent lower gastrointestinal system endoscopy is benign diseases of the anorectal region. It was reported that hemorrhoidal disease is found in the United States at a frequency of $50 \%$ and in our country at $15 \%-30 \%{ }^{13,18,19}$ In our study, hemorrhoids were present in $27 \%$, anal fissures in $6.7 \%$, and perianal fistulas in $0.7 \%$ patients. In a study by Bowles et al. ${ }^{17}$, it was reported that the normal CS rate was $42.1 \%$, polyps were present in $22.5 \%$, diverticula were seen in $22 \%$, and inflammatory bowel disease was present in $13.9 \%$ of the cases. In a study conducted by Özsoy et al. ${ }^{18}$, it was reported that $34.4 \%$ of the patients had normal CS findings, $4.2 \%$ had diverticulum, 3.1\% had inflammatory bowel disease, $0.7 \%$ had a solitary rectal ulcer, and $0.5 \%$ had angiodysplasia. The normal CS rate was $34.3 \%(783 / 2,285)$ in our study. The normal colonoscopy count was 732 (34.6\%) in the Turkish patient group and 51 (29.8\%) in the Syrian patient group; this difference was statistically significant. In addition, diverticulum was detected in $2.9 \%$ and solitary rectal ulcer in $0.4 \%$ of our patients.

Among the diseases that cause lower gastrointestinal symptoms, the most feared pathology is colorectal cancer. Colorectal cancers, the most common malignancy of the 
gastrointestinal tract, are the fourth most common cancer type to cause deaths worldwide. ${ }^{20}$ Colorectal cancers are among the top five cancers in both women and men in our country. ${ }^{21}$ CS is the most reliable diagnostic method for screening and diagnosis of colorectal cancer. The rate of colorectal carcinoma was $1.7 \%$ in our study. This rate was found to be significantly lower than the literature findings, which may be due to differences in socio-economic status, nutritional habits, and CS indications between regions. The prevalence of inflammatory bowel disease varies with age, gender, geographic region, ethnicity, and socio-economic level. In a study on clinical populations of the Western Black Sea region of Turkey, the prevalence of ulcerative colitis and Crohn's disease were reported as 31.83/100,000 and $12.53 / 100,000$, respectively, and their average annual incidence was $4.87 / 100,000$ and 2.09/100,000, respectively. ${ }^{22}$ The rate of inflammatory bowel disease detection was 3.6\% in our study.

Tissue masses protruding from the intestinal mucosa toward the lumen are called polyps. Most colorectal polyps are asymptomatic and are found incidentally. They are often seen in the left colon and rectum. Polyps are classified histologically as neoplastic or non-neoplastic. Neoplastic polyps, which has a group of colon polyps, constitute approximately $2 / 3$ of all colon polyps. Adenomatous polyps are classified histologically as tubular, tubulovillous, or villous. ${ }^{23}$ Colorectal cancers may develop from the adenoma level. Therefore, it is recommended that the polyps detected during colonoscopy should be completely removed regardless of the size for histopathological diagnosis. In two large-scale studies in the literature, the rate of polyp detection was reported as between $20.1 \%$ and $32.5 \% .^{24,25}$ In various studies conducted in our country, the prevalence of polyps was reported as between $11.1 \%$ and $34.9 \% .^{18,26,27,28} \mathrm{In}$ our study, we detected polyps in 324 patients throughout 2285 CSs in total, and our polyp detection rate was $14.2 \%$. The polyp detection rate was $14.6 \%$ in the Turkish patient group and $8.8 \%$ in the Syrian patient group. These rates were lower than the data reported in the literature.

The most common complications associated with CS are bleeding and perforation. In a large-scale study conducted by Laanani et al..$^{24}$, bleeding at a rate of $0.065 \%-0.23 \%$ and perforation at a rate of $0.035 \%-0.073 \%$ were reported after CS. In our study, complications were seen in four $(0.17 \%)$ patients after the CS. Bleeding was observed in two (0.08\%) patients after colonoscopic polypectomy, and perforation was observed in two $(0.08 \%)$ patients.

\section{Study Limitations}

Our study had some significant limitations. Our study was a retrospective observational study. The number of patients was limited in number compared to the single-center and incomplete CS studies in the literature. There were no data on the factors such as adherence to the bowel cleansing protocol affecting the insufficient bowel cleansing and bowel cleansing solutions used. The most important limitation was the numerical difference between the patient groups compared. Our study's most important advantage is that two different patient groups were compared demographically and socio-culturally, which is different from the design of many other CS studies in the literature.

\section{Conclusion}

Our study resulted in a high rate of incomplete CS and insufficient bowel cleansing and a low rate of polyp detection in the Syrian patient group, which did not achieve the literature recommendations. We think that this might have been due to the incompatibility of bowel cleansing preparation information before the procedure, which is caused by the current socio-economic conditions and communication problem (language disability) in our region. Therefore, we believe that the preparation of informed consent forms and bowel cleansing forms translated from Turkish to Arabic and increasing the number of qualified interpreters may reduce this problem, especially in centers where the Syrian patient population is intense, such as in our region.

\section{Ethic}

Ethics Committee Approval: The study was approved by the Harran University Clinical Studies Ethics Committee (approval no: HRU/20.11.37).

Informed Consent: Since the study was designed retrospectively, data were collected from the clinical archive. Peer-review: Externally peer reviewed.

\section{Authorship Contributions}

Surgical and Medical Practices: D.A.Ç., M.P., Concept: D.A.Ç., M.P., Design: D.A.Ç., Data Collection or Processing: D.A.Ç., Analysis or Interpretation: D.A.Ç., M.P., Literature Search: M.P., Writing: D.A.Ç.

Conflict of Interest: No conflict of interest was declared by the authors.

Financial Disclosure: The authors declared that this study received no financial support.

\section{References}

1. Brenner H, Chang-Claude J, Jansen L, Knebel P, Stock C, Hoffmeister M. Reduced risk of colorectal cancer up to 10 years after screening, surveillance, or diagnostic colonoscopy. Gastroenterology 2014;146:709717

2. Rex DK, Schoenfeld PS, Cohen J, Pike IM, Adler DG, Fennerty MB, Shaheen NJ. Quality indicators for colonoscopy. Gastrointest Endosc 2015;81:3153. 
3. Cappell MS, Friedel D. The role of sigmoidoscopy and colonoscopy in the diagnosis and management of lower gastrointestinal disorders: technique indications, and contraindications. Med Clin N Am 2002;86:1217-1252.

4. Levin B, Lieberman DA, McFarland B, Andrews KS, Brooks D, Bond J, Dash C, GiardielloFM, Glick S, Johnson D, Johnson CD, Levin TR, Pickhardt PJ, Rex DK, Smith RA, Thorson A, Winawer SJ. Screening and surveillance for the early detection of colorectal cancer and adenomatous polyps, 2008: a joint guideline from the American Cancer Society, the US Multi-Society Task Force on Colorectal Cancer, and the American College of Radiology. Gastroenterology 2008;134:1570-1595.

5. Winawer S, Fletcher R, Rex D, Bond J, Burt R, Ferrucci J, Ganiats T, Levin T, Woolf S, Johnson D, Kirk L, Litin S, Simmang C. Colorectal cancer screening and surveillance: clinical guidelines and rationale-Update based on new evidence. Gastroenterology 2003;124:544-560.

6. Jung SA. Differential diagnosis of inflammatory bowel disease: what is the role of colonoscopy? Clin Endosc 2012;45:254-262.

7. Koido S, Ohkusa T, Nakae K, Yokoyama T, Shibuya T, Sakamoto N, Uchiyama K, Arakawa H, Osada T, Nagahara A, Watanabe S, Tajiri H. Factors associated with incomplete colonoscopy at a Japanese academic hospital. World J Gastroenterol 2014;20:6961-6967.

8. Franco DL, Leighton JA, Gurudu SR. Approach to Incomplete Colonoscopy: New Techniques and Technologies. Gastroenterol Hepatol 2017;13:476483.

9. Neerincx M, Terhaar sive Droste JS, Mulder CJ, Räkers M, Bartelsman JF, Loffeld RJ,Tuynman HA, Brohet RM, van der Hulst RW. Colonic work-up after in complete colonoscopy: significant new findings during follow-up. Endoscopy 2010;42:730-735

10. Johnson DA, Barkun AN, Cohen LB, Dominitz JA, Kaltenbach T, Martel M, Robertson DJ, Boland CR, Giardello FM, Lieberman DA, Levin TR, Rex DK. US Multi-Society Task Force on Colorectal Cancer. Optimizing adequacy of bowel cleansing for colonoscopy: recommendations from the US MultiSociety Task Force on Colorectal Cancer. Gastroenterology 2014;147:903924.

11. Lai EJ, Calderwood AH, Doros G, Fix OK, Jacobson BC. The Boston bowel preparation scale: a valid and reliable instrument for colonoscopy-oriented research. Gastrointest Endosc 2009;69:620-625

12. Calderwood AH, Jacobson BC. Comprehensive validation of the Boston Bowel Preparation Scale. Gastrointest Endosc 2010;72:686-692.

13. Smith RA, Cokkinides V, Eyre HJ. American Cancer. Society. American Cancer Society guidelines for the early detection of cancer. CA Cancer J Clin 2003;53:27-43.

14. Rutherfor CC, Calderwoo AH. Update on bowel preparation for colonoscopy. Curr Treat Options Gastroenterol 2018;16:165-181.
15. Aday U, Gündeş E, Çiyiltepe H, Çetin DA, Bozdağ E. Akbulut S, Polat E. Compliance with quality standards and causes of incomplete colonoscopy: a prospective observational study. Turk J Colorectal Dis 2019;29:25-32.

16. Hendry PO, Jenkins JT, Diament RH. The impact of poor bowel preparation on colonoscopy: a prospective single-center study of 10,571 colonoscopies. Colorectal Dis 2007;9:745-748

17. Bowles CJ, Leicester R, Romaya C, Swarbrick E, Williams CB, Epstein O. A prospective study of colonoscopy practice in the UK today: are we adequately prepared for national colorectal cancer screening tomorrow? Gut 2004;53:277-283

18. Korkmaz H, Kendir İC, Kerpiç O. Evaluation of colonoscopy outcomes with the indications, complications, and success of the procedure in our gastroenterology unit. Endoscopy Gastrointestinal 2015;23:9-13.

19. Özsoy M, Celep B, Ersen O, Özkececi T, Bal A, Yılmaz S, Arıkan Y. Our results of lower gastrointestinal endoscopy: evaluation of 700 patients Ulus Cerrahi Derg 2014;30:71-75.

20. Arnold M, Sierra MS, Laversanne M, Soerjomataram I, Jemal A, Bray F. Global patterns and trends in colorectal cancer incidence and mortality. Gut 2017;66:683-691

21. Gültekin M, Boztaș G, eds. Türkiye Kanser İstatistikleri. Sağlık Bakanlı̆̆ı, Türkiye Halk Sağlığı Kurumu. 2014: 43.

22. Can G, Poşul E, Yılmaz B, Can H, Korkmaz U, Ermiş F, Dağlı Ü. Epidemiologic features of inflammatory bowel disease in the Western Blacksea region of Turkey for the last 10 years: a retrospective cohort study. Korean J Intern Med 2019;34:519-529.

23. Lieberman DA, Rex DK, Winawer SJ, Giardiello FM, Johnson DA, Levin TR. Guidelines for colonoscopy surveillance after screening and polypectomy: a consensus update by the us multi-society task force on colorectal cancer. Gastroenterology 2012;143:844-857.

24. Laanani M, Coste J, Blotière PO, Carbonnel F, Weill A. Patient, procedure, and endoscopist risk factors for perforation, bleeding, and splenic injury after colonoscopies. Clin Gastroenterol Hepatol 2019;17:719-727.

25. Bannert C, Reinhart K, Dunkler D, Trauner M, Renner F, Knoflach P, Ferlitsch M. Sedation in screening colonoscopy: impact on quality indicators and complications. Am J Gastroenterol 2012;107:1837-1848.

26. Solakoğlu T, Atalay R, Köseoğlu H, Sarı SÖ, Bolat AD, Akın E,Yürekli ÖT, Selvi E, Büyükaşık Ş, Ersoy O. Analysis of 2222 colorectal polyps in 896 patients: A tertiary referral hospital study. Turk J Gastroenterol 2014:25:175-179

27. Şahintürk Y, Çekin AH. Colon polyps localization, histology, and size - five years colonoscopic research. Endoscopy Gastrointestinal 2018;26;57-60.

28. Temiz A, Kaya A. Histopathological results of colonoscopic polypectomy in a surgery unit. Endoscopy Gastrointestinal 2017;25:62-65. 